\title{
Structural Shifts in Translation of Children's Literature
}

\author{
Monireh Akbari \\ Islamic Azad University, Science and Research Campus, Tehran, Iran \\ E-mail: mnr.akbari@yahoo.com
}

Received: February 12, 2012 Accepted: February 17, 2012 Published: June 1, 2012

doi:10.5296/ijl.v4i2.1911 URL: http://dx.doi.org/10.5296/ijl.v4i2.1911

\begin{abstract}
As far as translation is concerned, the notion of "shift" is admittedly one of the most important areas to be investigated. This phenomenon has been analyzed, evaluated and extensively discussed from different points of view and has been approached from many different perspectives by many researchers. The multitude of issues on types of "shift" bears testimony to its significance within the framework of the reflection on translation.

In the current study, the researcher's intention was to focus upon the types of "structural shifts" in literary translation from English into Persian and their significant role in Compensation and Explicitation of meaning.

The main objective of this research was to see whether and how translators incorporate structural shifts into their schedule, what kinds of structural Shift are made and what kinds of structural shift are more frequently used in literary translation. The second objective of the research was to examine whether structural shifts help the literary translators to better transfer the meaning.
\end{abstract}

Keywords: Structural Shifts, Literary Translation, Persian, Compensation, Explicitation 


\section{Introduction}

As far as history has reported children`s literature was conspicuously didactic and educational before the 19th century.( Carpenter \& Prichard, 1984; Sarland, 2004) It conveyed religious doctrines with an attempt to incorporate a sense of morality and the right ways of life in the minds of children.(Bingham, 1988) Children`s literature provided young audiences with information that was deemed useful for their education. After the 19th century the objectives of children's literature got blurred and the didactic purposes were not portrayed as vividly as before. And the ideas about children and childhood changed along with the social changes toward an industrial society.

Most researchers are of the opinion that the children`s upbringing has to be first and foremost in literary translation. (Baker, 1992; Toury, 1995)The fairy tales make frequent references to prayers, gratitude, respect and humility - in other words, they contain many spiritual elements. Researchers believe that the upbringing should be patriotic. Home and childhood memories represented the fatherland in the fairy tales. Similarly, moral and educational ideas such as humility, diligence, spirit of comradeship, love, truth and victory over self, are recurring themes in fairy tale translation (Hermans, 1985).

Since transfer of these elements is not performed directly and is not without its difficulties, the act of translation can be analyzed along a range of possibilities, which brings about a number of shifts, specially the structural shifts in translation. In this study, the researcher has attempted to deal with a common phenomenon in literary translation which is structural shift. The major aim was to provide an analysis of types of structural shift in literary translation at various levels of linguistic and paralinguistic description.

\section{Literature Review}

Since 1950s, there have been a variety of linguistic approaches to the analysis of translation that have proposed detailed lists or taxonomies in an effort to categorize the translation process. One of the best - known and most representative phenomena in translation process is "Shift in translation".

The term "shift" is used in the literature to refer to changes which occur or may occur in the process of translating. Since translating is a type of language use, the notion of shift belongs to the domain of linguistic performance, as opposed to that of theories of competence.(Blum-Kulka, 1986)

Hence, shifts of translation can be distinguished from the systemic difference which exists between source and target language and cultures. Systemic differences, which pertain to the level of competence, are part of the opening condition for translation. (Blum-Kulka, 1986).

As a descriptive category, shifts are defined and identified retrospectively. They are reconstructed or reestablished during the description of actual, existing translations. The descriptive focus may be on the reconstruction of the translation process, or on the product, particularly with respect to its relation to the source. However, the distinction between process -oriented and product- oriented description is not clear -cut. Process - related elements may 
play a role within the description of the product is the principal means for describing translation as a process (Lefever, 1979).

When the focus is on the process, typologies of shifts generally attempt to account for the nature of translation operations and the considerations underlying certain decisions taken during the course of translation. Because the translation process is essentially a "black box" (Holmes, 1972), any classification of shifts at this level has to be based on translation competence, that is, on the possible relationship and differences between systems or codes. But, since the empirical testing of cognitive, processes involved in translation is problematic (THINK- ALOUD PROTOCOLS), process-oriented typologies tend to reduce theoretical,general translation competence to a specific translation ideal. A distinction is often made between obligatory and optional shifts (Robberecht, 1982; Toury, 1980; Van Den Broeck \& Lefevere, 1979; Van Leuven - Zwart, 1989).

Obligatory Shifts are dictated by differences between linguistic systems, for example a lack of correspondence between related lexical items in the source and target languages (Kade, 1968).

As far as the product - oriented view of shifts is concerned, the definition by Popovic(1970) may serve as a starting point : "all that appears as new with respect to the original, or fails to appear where it might have been expected , may be interpreted as a shift." In this definition, three elements can be discerned: (a) a relationship between the source and target texts (new with respect to the original); (b) a relationship between the target text and its reception in the target system (where it might have been expected); and (c) a descriptive point of view (may be interpreted). The descriptive focus can be either on (a) or on (b). For example, a zero - shift established at specific textual or linguistic levels in the source / target - text relationship (i.e. an instance of invariance, where nothing new appears)may still be interpreted as a shift in terms of (b) : by violating the expectations of the target system, a target text may acquire a function other than fulfilled by the source system. This double point of view implies that there is always the possibility of a description in which shifts are sometimes called a categorical quality (Van Den Broeck, 1984) of the class of translation. This quality can be casually linked to the double status of the translation as a text function in its own right in the target culture.

Any typology of shifts presupposes a descriptive point of view. Although Vinay and Darbelent (1995) do not use the word "shift", in discussing translation shift, that is in effect what they are describing. The term itself seem to originate in Catford 's."A Linguistic Theory of Translation" (1965), where he follows the Firthian and Hallidayan linguistic model which analyzes language as communication, operating functionally in context and on a range of different levels (e.g. phonology, graphology, grammar, lexis) and ranks ( sentence, clause, group, word, morpheme, etc.)(Catford, 1965)

As far as translation is concerned, Catford(1980) makes an important distinction between formal correspondence and textual equivalence.

- A formal correspondent is any TL category ( unit, class, element of structure, etc.) which can be said to occupy, as nearly as possible, the "same" place in the "economy" of the TL as the given SL category occupies in the SL.(Blum-Kulka, 1986) 
- A textual equivalent is "any TL text or portion of text which is observed on a particular occasion ... to be the equivalent of a given SL text or portion of text."

Catford (1980) considers two kinds of shift: (1) Shift of level and (2) shift of category 1. A level shift would be something which is expressed by grammar in one language and lexis in another .It has already been pointed out that translation between either of phonology and graphology - or between either of these levels and the levels of grammar and lexis is impossible. Translation between these levels is absolutely ruled out by the theory, which posits relationship to the same substance as the necessary condition of translation equivalence. We are left then with shifts from grammar to lexis and vice - versa as the only possible level shift in translation and such shifts are, of course, quite common.Examples of level shift are sometimes encountered in the translation of the verbal aspects of Russian and English. Both these languages have an aspectual opposition - of very roughly the same type.

2. Most of Catford`s analysis is given over to category shifts. The concept of 'category - shift ' is necessary in the discussion of translation but it is clearly meaningless to talk about categoryshift unless we assume some degree of formal correspondence between SL and TL, indeed this is the main justification for the recognition of formal correspondence in theory. Category shifts are departures from formal correspondence in translation.Category shifts involve structure shifts, class shifts unit shifts (rank - changes) and intra system shifts (Catford, 1980).

a) Structure shifts:

These are said by Catford (1980) to be the most common form of shifts and to involve mostly a shift in grammatical structure . For example, the subject pronoun + verb + direct object structures in English and French are translated by an indirect object pronoun + verb subject pronoun structure in Spanish and in Italian, or a subject - predicate - object structue may be translated as a predicate - subject - object structure.

b) Class shifts:

Class shifts occur when the translation equivalent of a SL item is a member of a different class from the original item. Class shifts comprise shifts from one part of speech to another. An example given by Catford is the English "a medical student" and its French equivalent, where the English premodifying adjective . "Medical" is translated by the adverbial qualifying phrase, in French (Catford, chapter 4).

An adjective may be translated by a noun or a verb.

c) Unit shifts or rank shifts:

These are shifts where the translation equivalent in the TL is at a different rank to the SL . «Rank» refers to the hierarchical linguistic units of sentence, clause, group, word and morpheme.

A word may be translated by a morpheme or a group by a morpheme or a group by a clause (ibid). 
d) Intra - system shifts:

There are shifts that take place when the SL and TL possess approximately corresponding systems but where the translation involves selection of a non-corresponding term in the TL system . Examples given between French and English are number and article system. Although similar systems operate in the two languages, they do not always correspond. So, singular noun in English becomes a plural correspondence in French, or definite article in French becomes indefinite article in English (ibid).

Catfords model is an important attempt to apply to translation advances in linguistics in a systematic fashion. However, his analysis of intra-system shifts betrays some of the weakness of his approach. From his comparison of the use of French and English article systems in short parallel texts, Catford (1980) concludes that French Le/La/Les will have English the as its translation equivalent with probability, supporting his statement that "translation equivalence does not entirely match formal correspondence". This kind of scientific - like statement of probability, which characterize Catford`s whole approach and was linked to the growing interest in matching translation at the time, was later heavily cristicized by, amongst others. Delisle (1982) for its static comparative linguistic approach, Henry (1984), reviewing Catford`s book twenty years after publication, considers the work to be،by and large of historical academic interest only (Baker, 1992).

Catford's approach to translation clearly differ from that adopted by Nida(Nida \& Taber, 1969), since Catford had a preference for a more linguistic - based approach to translation and this approach is based on the linguistic work of Firth and Halliday. His main contribution in the field of translation theory is the introduction of the concepts of shifts in translation. Catford proposed very broad types of translation in terms of three criteria:

1) The extent of translation (full translation VS partial translation)

2) The grammatical rank at which the translation equivalence is established (rank - bound translation versus unbounded translation)

3) The levels of language involved in translation (total translation versus restricted translation)

Among all factors affecting the occurrence of stylistic shifts, the role of the translator stands as the most recognizable factor. The majority of optional shifts taking place in translation can be attributed to the differences between the original writer and the translator as two texts producers. However, the impacts of these differences are usually suppressed by the literary norms of the TL and the norms of the translation activity itself. More important is the translator`s relation to the text given. This relation is neatly described by Popovic (1970, p. 80) as fallows:

It is not the translator's only business to "identify" himself with the original; that would merely result in transparent translation. 
The translator also has the right to differ organically, to be independent, as long as independence is pursued for the sake of the original, a technique applied in order to reproduce it as a living work ...

Thus shifts do not occur because the translator wishes to 'change' a work, but because he strives to reproduce it as faithfully as possible and to grasp it in its totality.

Within the methodology of Toury(1990), the invariant of the comparison is the Adequate Translation (AT) and the unit of comparison is a reconstruction of source text textemes and consists of an explicitation of the textual relation and functions of the source text. As such, it is not an actual text but a hypothetical construct, serving only methodological purposes. The purpose of comparison is to determine the distance between 'actual equivalence' found between source and target texts and the maximal norms of adequate translation, in as much as this distance can be attributed to norm - governed translation behavior. Since obligatory shifts are ruled - governed, they can not be taken to reflect translational NORMS and are therefore not taken into consideration; methodologically, they are accounted for in the dominant relationship between target - text texteme and source - text unit is found at that level, the translational relationship is one of adequacy. When there is no textual - functional correspondence the procedure is to look for correspondence at lower textual and linguistic levels. Norms determine the position of the actual translation equivalence between adequacy and acceptability, and the establishment of individual shifts ultimately leads to the establishment of the translational norms governing the text in question. when, after further generalization and expansion of the investigated corpus, shifts show a certain pattern of statistical regularities, they can be explained by the existence of a historically and culturally determined POETICS OF TRANSLATION or translation ideal (Baker, 1992).

In later stages of Toury`s thinking $(1985,1990)$, the above procedure became part of a larger one in which an additional unit of comparison was introduced: the couple pair of "problem + solution". The notion of shift gradually became less central in his method of description. Within the methodology of Van Leuven Zwart (1984, 1989, 1990), a distinction is made between shifts at the level of a text's microstructure (comparative model) and the effects of these shifts at the macrostuctural level (descriptive model). At the micro structural level, the invariant of the comparison is the architranseme (ATR), which expresses the common denominator(s) in the relation between specific textual units of the source and target texts; these textual units are called transemes. In as much as the descriptive model is comparative, it works with an invariant at the macro-structural level as well. The invariant in this case is based on a theory of the genre to which the texts under comparison belong. Van Leuven Zwart limits her methodological concepts such as `story level` and `focalization. The ATR has to be established separately for macro-structural level will be established a priori (Vinay, J.P. \& J. Darbelnet, 1995). Essential to the method of Van Leuven-Zwart is the priority givento the concept of relation. Any comparativedescription involves establishing the relation between elements as well as attributingcertainfeaturestothoseelements.AccordingtoVanLeueven-Zwart, a comparison based on the priori attribution of features is only a 'second degree comparison', since it departs from a descriptive operation, and the relationship between the elements is 
established afterwards. In a direct comparison, the order is reversed. According to this scheme, a texteme, for instance, would be a unit of description rather than a unit of comparison. At the micro-structional level, a relation of complete conjunction between the transemes and archi - transemes (in which case there is a relation of synonymy between transemes) is assumed as a starting point, and shifts occur when there are aspects of disjunction between transemes and the ATR. Van Leuven - Zwart distinguishes three main categories: modulation (where a source or target transeme shows one or more aspects of disjunction with the ATR ; a relation of hyponomy between transemes ), modification (where a source or target transeme show one or more aspects of disjunction with the ATR can be established; no relation between transemes) (Lefever,1979).

The main argument postulated is that the process of translation necessarily entails shifts both in textual and discoursal relationships. The argument is developed by adopting a discoursal and communicative approach to the study of translation. It is assumed that translation should be viewed as an act of communication, as in the study of all act of communication, consideration of both the process and the product of the communicative act necessarily relate to at least the linguistic, discoursal and social systems holding for the two languages and cultures involved (Fawcett, Peter, 1997)

On the level of cohesion, shifts are used in translation in one or both of the following directions:

A. Shifts in levels of explicitness; i.e the general level of the target texts` textual explicitness is higher or lower than that of the source text.

B. Shifts in text meaning (s), i.e. the explicit and implicit meaning potential of the source text changes through translation. Shifts in text meaning results in compensation of meaning.(ibid)

The overt cohesive relationships between parts of the texts are necessarily linked to a language`s grammatical system (Halliday \& Hassan, 1976). These structural differences between languages will be expressed by changes in the types of ties used to mark cohesion in source and target texts. Such transformations might carry with them a shift in the text's overall level of explicitness (Snell-Hornby, 1988).

On a higher, textual level, shifts in levels of explicitness though translations have been claimed to be linked to differences in stylistic preferences for types of cohesive markers in the two languages involved in translation. Levenston (1976) and Berman (1978) have contrasted English and Hebrew, and noted the preference of Hebrew for lexical repetition or pronominalization. Levenston claims that given the choice between lexical repetition and pronominlization, Hebrew writers tend to prefer the former while English writers tend to choose the latter. Berman modifies this claim by arguing that both in Hebrew and in English, pronominalization is preferred whenever possible, but since achoice is often not grammatically possible in Hebrew, in fact lexical repetition is far more frequent in Hebrew than in English . A similar claim has recently been made for Portuguese and English (Viera, 1984), namely that 
cohesive features in Portuguese reflect a stroger need for clarity and a higher degree of specification than English (ibid).

The phenomenon depicted in these studies might indeed indicate different norms governing the use of particular cohesive devices in the source and target languages. Such differences may also, however, be ascribed to constrains imposed by the translation process itself (ibid).

For lack of large - scale empirical studies that might validate either or both the "stylistic preference" and " the explicitation " hypothesis, more evidence for the latter might be sought by examining different types of structural shifts in literary texts (Van den Broeck, 1984, p.5).

It might be the case that explicitation is a universal strategy inherent in the process of language mediation, as practiced by professional and non - professional translators alike (ibid).

The structural shifts caused in the translation of literary texts are by no means unusual. They fit in with the trend for compensation of meaning. In literary texts, where the short lines of seemingly ordinary talk are so heavy with implied meanings, each structural shift has crucial consequences for the interpretation of those meanings (ibid).

In line with the reviewed literature, in this study, the researchergs intention was to focus on the types of «Structural Shifts» in literary translation from English into Persian and their significant role in Compensation and Explicitation of meaning. To fulfill the purpose of this study the following research questions were raised:

1) What are the most common structural shifts in literary translation from English into Persian?

2) Do structural shifts affect the meaning through explicitation or compensation?

\section{Research Methodology}

The aim of the present work was to shed some light on the process of structural shifts in literary translation. The researcher`s aim was to find out the most common structural shifts through comparative analysis of structures between texts written in English and texts translated into Persian.

\section{Material}

The corpus used for the purpose of this study was a non -automated bilingual English -Persian corpus of children's literature. In order to accomplish the above task, the researcher used ten Read - Aloud story books written in English for children and samples of their translation in Persian.

The story books contained some $40-60$ pages. The books used for the purpose of the present study were as follows. For detailed bibliographical information, please see the References (English):

(1) Where the Sidewalk Ends (Shel Silverstein, 2003) translated by Razi Khodadadi (Hirmandi) (1381) 
(2) Toy story (Walt Disney`s.Dan Fontes \& Yustine Corman, 2003 ) translated by Hasan Ghaemmaghami (1381)

(3) Aladdin (Walt Disney`s, 2002) translated by Maryam Ghanesherbaf (1383)

(4) Cinderella (Walt Disney`s, Dela Cohn, 2002) translated by Hasan Ghaemmaghami (1382)

(5) Beauty and the Beast (Walt Disney`s, 2003) translated by Maryam Ghanesherbaf (1383)

(6)Sherek 1 (Walt Disney`s, 2004) translated by Hasan Ghaemmaghami (1383)

(7)Sherek 2 (Walt Disney`s, 2004) translated by Hasan Ghaemmaghami (1383)

(8)Goofy and Friends(Walt Disney`s, 2004) translated by Maryam Ghanesherbaf (1383)

(9)Finding Nemo (Walt Disney`s, 2004)translated by Maryam Ghanesherbaf (1383)

(10)The Batman (Walt Disney`s, 2004) translated by Keyvan Rostami (1383)

\section{Procedure}

The researcher applied the method of comparison between source texts (English texts) and samples of translation in Persian. All sentences or paragraphs of each source text were compared with their sample translation in Persian.

All structures were analyzed manually and the samples of structural shifts were identified and classified in tables under the following titles:

- Addition / Omission

- Word Order Re-arrangement

- Sentence Voice

- Sentence Tense

Among the samples of structural shifts which were identified, the common ones are presented and discussed in respect of their possible effects on transfer of meaning through compensation and explicitation.

\section{Data analysis}

The data collected were analyzed and categorized. Structural shifts were classified under (1) Addition, (2) Omission, (3) Arrangement, (4)Shift of Voice, and (5)Shift of Tense.

\subsection{Addition}

By addition it is meant that the translator adds grammatical elements to transfer the intended meaning.Somescholars and researchers includingLefever(1979), Berman(1978) and Holmes(1972) certain define this phenomenon as "Gain" in translation process. Addition itself is further classified into the following subtitles.

\section{A. ad-clause}


(1)adjectival clauses

(2)adverbial clauses

Adverbial clauses and adjectival clauses are translated in a structure different from that of source text; something is added in order to reflect the intended message.

Examples:

In a flash, there were also tiny glass slippers for her feet.

$$
\text { به يك جشم بر هم زدن كفش هاي ظريف بلورين بر اي باهايش فر اهم شد. }
$$

On the stroke of midnight, the spell will be broken, the fairy Godmother warned. "Every thing will be as before"

$$
\text { فرشته نجات هشدار داد: }
$$

B. adv-addition:

There are some English verbs that bear some intra adverbial- meaning. When these verbs are translated into Persian, adverbs of state are added to the grammatical structural of target text.

Examples:

Then the other mice could scoot outside.

$$
\text { بعدش بقيه ي موش ها مي توانستند سريع بيرون بدوند. }
$$

Woody sent the green army men to spy on the birthday party.

$$
\text { وودي سرباز ان سبزيوش را فرستاد تا مخفيانٍ مهماني جشن تولد را زير نظر بكيرند. }
$$

Meanwhile, at the royal palace, the king complained to the Grand Duke. "It s high time my sun got married " He sobbed, "I want grand children!"

$$
\begin{aligned}
& \text { در اين بين , در قصر سلطنتي, بادشاه بيش دوك اعظم كلايه مي كرد و هق هق كنان مي كفت : "وقتش شده كه }
\end{aligned}
$$

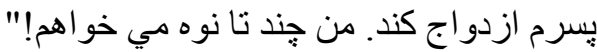

C. Verbiage

By verbiage the it is meant the use of too many words than are needed to express an idea .

Examples:

Birthday meant new toys for Andy to love, and someone might get replaced!

$$
\text { كنار كذاشتن يكي از اسباب بازي هناب ورود اسباب بازي هابي جديد به خانه اندي بود و علاقمند شدن اندي به اسباب بازي جديدو }
$$

Let's give whatever it is up there a nice, big, Andy`s room welcome. 


\section{Macrothink}

International Journal of Linguistics

ISSN 1948-5425 2012, Vol. 4, No. 2

بيائين از اون كسي كه بالاي تخته ــ هر جي مي خو اد باثشه - يك استقبال كرمو درست و حسابي به عمل بياوريم و ورودشو به اناق اندي خوشامد بكيم.

D. Mood:

Sometimes addition in translation affects degree of mood. Some translators add something in order to make the mood of the text more potential, indicative or imperative.

(1)Imperative:

Example:

Open in the name of the king.

$$
\text { بهن نام اعليحضرت در را باز كنيد. }
$$

Reach for the sky! You're going to jail, one - eyed Bart!

$$
\text { دست ها بالإ! تو مي ري زندان بارت يك جشم! }
$$

Go get your sister.

$$
\text { برو خواهرنوييدا كن بيارش. }
$$

(2)Indicative:

Examples:

The mice yelled, "Surprise!"

$$
\text { موش ها فرياد زدند : "اين جا را باش". }
$$

Cindrella was in rags.

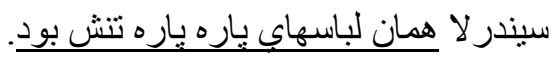

okey, everybody, it's clear!

$$
\text { همه كَّش كنين, همه جا امن و امانه. }
$$

(3) Potential

Examples:

Let me out.

$$
\text { بكذاريد بيرون بيايم. }
$$

Okay, birthday boy.

خب , آقاي يِري كه امروز روز نولدته.

To infinity and beyond!

ييش به سوي فضاي لايتناهي و فراتر از لايتناهي. 


\subsection{Omission}

By omission it is meant that the translator omits something (grammatical elements). Some scholars and researchers including Popovic(1970) and Berman(1978) definethis phenomenon as "Loss" in translation process.

Sometimes some grammatical elements are left out in the process of translation. Some define this phenomenon as "Loss", in translation.

Examples:

Leaping lamp oil!

$$
\text { اي واي! }
$$

In a blinding flash of light, Goofini finds himself lost in an ancient Egyptian Pyramid.

$$
\text { در يك جشم بـ هم زدن كوفي خودش را در يك هرم باستاني مصر بيدا مي كند. }
$$

Among them there was a spoken donkey that his owner wanted to sell him but the donkey didn't agree.

$$
\text { در بين آن ها يك خر سخن گو هم بود. خر سخن گو نمي خواست صاحبش او را بفروشد. }
$$

\subsection{Arrangement}

Sometimes shift of arrangement happens in the process of translation. It can be either shift in subject / predicate, shift in adverb position or shift in the order of grammatical elements. So shift of arrangement was classified under the following subtitles :

\section{A. S./predicate}

Examples:

What's all the fuss about.

$$
\text { اين همه جار و جنجال بر اي جيست؟ }
$$

But Jaq was too fast for $\underline{\text { Lucifer }}$ and made it safely in to a mousehole.

$$
\text { را به ولي سر اخ مت ز الك خيلي بيشنر از آن بود كه لوسيفر از يس او بر آيد. زاك كارش را به سلامت به آخر بردو خودش }
$$

Sid had a scary gleam in his eyes.

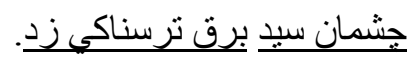

Every eligible maiden is supposed to attend.

$$
\text { قر ار است هر دوشيزه ي واجدشر ايطي در مهماني حضور يابد. }
$$

B. Adverb Position: 
In this type of structural shift based on language structure, the position of the adverb is changed .Sometimes an adverb in a source text appears in a different grammatical role in the target text.

Examples:

But her stepmother put the key in her pocket, laughing her meanest laugh.

$$
\text { اما نامادري اش خنده بسيار دزدانه هاي كرد و كلبد راتوي جيش كذاشت . }
$$

It fit perfectly.

$$
\text { درست قالب بِايش بود. }
$$

After Aladdin cleverly tricks Jafar into becoming a prisoner inside of a lamp, Genie is free to do whatever he wants.

$$
\text { بعد از اينكه علاءالدين باهوش به جعفر نيرنح زد تا داخل جر اغزنداني شود جيني آز اد است تا هر كاري خواست }
$$

C. Order of Grammatical Elements

Examples:

When it was time for Cinderella to feed the chickens, the mice headed for the barnyard.

$$
\text { وقتي موقعش شد كه سيندر لا غذاي مرغ و خروس ها را بدهد موش ها عازم حياط طو يله شدند. }
$$

Later that day, Cinderella heard a knock on the door.

$$
\text { ساعتي بعد در همان روز, سيندر لا شنيد در مي زنند. }
$$

Then she realized it was too late to get ready for the ball.

$$
\text { اين جا بود كه فهميد خيلي دير شده و نمي نو اند خودش را بر اي مجلس رقص آماده كند. }
$$

\subsection{Shift of Voice}

Sometimes the voice of text is changed in the process of translation. The shift of voice was classified under following subtitles:

\section{A. Passive to Active}

Examples:

Jaq was chosen to get the cat to chase him.

$$
\text { موش هاز الك را بركزيدند تا كاري كند كه كربه تعقيش كند . }
$$

Princess Jasmine`s single days are numbered.

$$
\text { برنس ياسمن روز هاي مجرديش تمام شده است. }
$$

She turned to welcome her father and was shocked to see that Philippe was alone!

$$
\text { به طرف او دويد تا به بدرش خوش آمد بكويد ـ ولي وقتي ديد كه فيليب تنهاست , بسيار تعجب كرد. }
$$


They were saved.

$$
\text { آنها نجات بافته بودند. }
$$

B. Causative to Non-Causative Verb

Examples:

I don't see why you can't go ... if you get all your work done, and if you can find something suitable to wear.

$$
\text { دليلي نمي بينم كه تو هم نتو اني بيايي ... به شرطي كه همه ي كار هايت را تمام بكني و بنو اني لباس مناسبي كير }
$$

بياوري.

C. Negative /Positive

Examples:

Woody couldn`t wait to bring Buzz home to prove that he wasn't a villain.

$$
\text { وودي بي قرار بود هر جه زودتر تكاور را به خانه ببرد و باعث تبرئه خود از اتهامات شرارت شود. }
$$

But his latest invention was not .

$$
\text { ولي اختر اع جديدش از بين رفته بود. }
$$

He shouldn`t have trespassed.

$$
\text { او خطا كرده است. }
$$

Keep an eye out for these dangerous - looking sharks shulking about in the underwater minefiled.

$$
\text { جشم از اين كوسه هاي به ظاهر خطرنالك كه در ميدان مين , زير آب يرسه مي زنند برنداريد. }
$$

\subsection{Shift of Tense}

Sometimes tense is changed in the process of translation. The shift of tense was classified under following subtitles:

\section{A. Present to Past}

Examples:

Jasmine believes this law is unfair, but many eligible princes have gathered in the palace garden for the chance to win her affection.

$$
\text { اند تا شانس بيدا كنند و در ازدو كواج با اين مد كم بي انصافي است , اما تعداد زيادي يرنس واجد شر ايط در باغ قصر جمع شده }
$$

As theyflee, Aladdin and Jasmine get separated in the crowd.

$$
\text { هنحامي كه آنها فرار مي كردند علاءالدين و ياسمن در شلوغي بازار هديكر را گم كردند. }
$$


Jafar promises the young man riches beyond belief if Aladdin will get the magic lamp from inside the cave of wonders.

جعفر به مرد جوان قول داد كه او را بيشتر از باور هايش ثروتمند كند بشرط آنكه علاءالدين جر اغ جادو را از داخل غار عجايب به دست آورد.

\section{B. Past to Present}

Later Andy`s mom told Andy it was time for dinner at pizza planet and Andy could bring only one toy.

جند لحظه بعد مامان اندي به او كفت كه وقت خوردن شام در بيتز ا فروشي سياره است و اين كه اندي مي تو اند فقط يكي از اسباب بازي هايش را با خودش بان بياورد.

Now Buzz know the truth : he was a toy!

$$
\text { اكنون متوجه و اقعيت شد و فهميد كه او اسباب بازي است ! }
$$

Lord told Shrek if he saved the princess, he would give him swamp again.

$$
\text { مرداب را دوباره به او مي دهد. }
$$

The researcher found 254 cases of structural shifts in 252 pieces of data collected . 50 cases were of addition type and 9 cases of omission type (Table 1). Among those cases of addition, 8 refer to ad - clauses (adjectival clauses: 2 cases and adverbial clauses: 6 cases). 18 cases are adverb- addition and 10 cases are verbiage . 14 cases are of mood types (potential: 5 cases, indicative: 6 cases and imperative: 3 cases.)

Among the structural shifts identified, 157 cases refer to those of arrangement (Table 2).

(subject / predicate: 29 cases, adverb position: 10 cases and order of grammatical elements: 118 cases) Among the structural shifts identified, 23 cases refer to those of voice (Table 3).(passive to active: 15 cases, causative to non - causative: 4 cases and negative / positive: 4 cases) Among the structural shifts identified, 15 cases refer to those of tense ( Table 4). (present to past: 11 cases and past to present: 4 cases.)

The most frequent structural shifts in literary translation from English into Persian are those of "arrangement". The most frequent shifts of arrangement are those of "grammatical elements order."

20.87 percent of structural shifts identified help literary translators in the compensation of meaning, 16.54 percent in explicitation of meaning and 62.59 percent of the shifts identified have a null role in transfer of meaning. Actually 62.59 percent of structural shifts happened based on structural nature and linguistic features of the target language (TL) or translators' taste (35.43 percent : structural nature and linguistic features of the target language and 27.16 percent: translators ' taste). 
Table 1.

\begin{tabular}{|c|c|c|c|c|c|c|c|}
\hline \multicolumn{8}{|c|}{ Addition /Ommision } \\
\hline \multicolumn{7}{|c|}{ Addition (Gain) } & Ommision \\
\hline \multicolumn{2}{|c|}{ Ad - clauses } & $\begin{array}{l}\text { Adv - } \\
\text { addition }\end{array}$ & verbiage & \multicolumn{3}{|l|}{ Mood } & 9 \\
\hline adjectival & Adverbial & \multirow[t]{2}{*}{18} & \multirow[t]{2}{*}{10} & Potential & Indicative & Imperative & \\
\hline 2 & 6 & & & 5 & 6 & 3 & \\
\hline
\end{tabular}

Table 2.

\begin{tabular}{|l|l|rr|}
\hline \multicolumn{2}{|l|}{ Shift of Arrangement } & Adv position & Order \\
\hline S./predicate & & $\begin{array}{r}\text { of } \\
\text { Elements }\end{array}$ \\
\hline 29 & & 10 & 118 \\
\hline
\end{tabular}

Table 3.

\begin{tabular}{|l|l|r|}
\hline \multicolumn{2}{|l|}{ Shift of Voice } & Negative / Positive \\
\hline Passive to active & $\begin{array}{l}\text { Causative to } \\
\text { Non-Causative Verb }\end{array}$ & \\
\hline 15 & 4 & \\
\hline
\end{tabular}


Table 4

\section{Shift of Tense}

Present to Past

Past to Present

11

\section{Conclusion}

Every language has its own linguistic characteristics and features, and that is why there are different languages. To convey a message, each language has its own wording system and forms, and these are to be changed when the same message is to be conveyed into another language, and it is this process of change which is called translation .

It is true that the main task of the translator is to transfer the message of the source - language text into the receptor language, but finding absolute equivalence is almost impossible to be actualized. The ideal and absolute equivalence of structure is a chimera, because languages have distinct codes and rules regulating the construction of grammatical stretches of languages and these forms have different meaning. The contrasting structures in two languages convey meanings which cannot but fail to coincide totally, and it is not the total meaning which is reproduced in the target language; something is always "lost", "added" or "altered" in the process of translation.

Although translation is not a form of synonymy, it is possible to translate a sentence from one language into another in numerous corresponding sentences which are synonyms of one another. This means that translation is not a prescribed thing without any alternative. Rather, the translation of a certain statement can be reworded or restructured in numerous lexical or grammatical synonyms conveying the same message in different wordings or structures. The phenomenon of structural shift is a positive consequence of the translator ${ }^{9} \mathrm{~s}$ effort to establish equivalence between two different language systems; that of the SL and that of the TL.

It is the occurrence of structural shifts that affects the translator's awareness of structural discrepancies between the SL and TL. In this sense, structural shifts which result from re-arrangement,addition,omission, change of sentence tense can be defined as problem-solving strategies adopted consciously by translators of literary texts, may minimize the inevitable loss of meaning, through explicitation and compensation when rendering a text from English into Persian.

\section{References}

Baker, M .( 1992 ) Routledge Encyclopedia Translation Studies. London and New York .

Berman ,R. (1978) Postponing Lexical Repetition and the Like a Study in Contrastive Stylistics . 


\section{Macrothink}

International Journal of Linguistics

ISSN 1948-5425

2012, Vol. 4, No. 2

Bingham, J. (1988). Writers for children : Critical studies of major authors since the seventeenth century. New York: Scribner's.

Blum- Kulka , S .(1986 ) Shifts of Cohesion and Coherence in Translation .

Carpenter, H. \& Prichard, M. (1984). The Oxford companion to children's literature. Oxford: Oxford University Press.

Catford , J.C.(1965/1980) A Linguistic Theory of Translation: An Essay in Applied Linguistics . London : Oxford University Press .

Cohn, D.(2002), Cinderella: Hirmand .

Disney’s,W .(2002) Aladdin : Danesh Moosavi .

Disney’s,W.( 2004) Goofy and Friends : Danesh Moosavi .

Disney's,W.(2003) Beauty and the Beast : Khaneye Adabiyat .

Disney's, W.(2004) Finding Nemo : Danesh Moosavi .

Disney's,W.(2004) Sherek 1,2 : Khaneye Adabiyat .

Disney's,W.(2004) The Batman : Danesh Moosavi .

Fonts, D. \& Corman ,Y.(2003) Toy Story :Hirmand .

Hermans, T. (ed.) (1985). The Manipulation of Literature: Studies in Literary Translation, Beckenham: Croom Helm.

Holmes , T.(1972) The Name and Nature of Translation Studies, Translation Across Cultures . New Delhi : Bahri Publications.

Lefever, A. (1979) Translating Literature Translated Literature - The State of the Art, Programmatic Second Thoughts on Literary and Translation

Leiden : E . J . Brill .

Nida , E . \& Taber ,C.(1969) The Theory and Practice of Translation.

Popovic , A .(1970) "The Concept” Shift of Expression in Translation, in Holmes , J. (ed) The Nature of Translation. Mouton: The Hague .

Sarland, C. (2004) "Critical tradition and ideological positioning." International Companion Encyclopedia of Children's Literature. Ed. Peter Hunt. London: Routledge, pp. 56-75.

Silverstein ,S.(2003) Where the Sindewalk Ends : Havaye Tazeh .

Snell - Hornby , M .(1988) Translation Studies : An Integrated Approach. Amsterdam and Philadelphia: John Benjamins.

Toury, G. (1995). Descriptive Translation Studies - and Beyond. Amsterdam : John Benjamin Pub. Co. 


\section{Macrothink}

International Journal of Linguistics ISSN 1948-5425 2012, Vol. 4, No. 2

Van den Broeck , R .(1984-5 ) Shifts in the Stylistics of Translate literary Texts : A Semiotic Approach.

Van Leuven - Zwart, Kitty M.(1984) Translation and Original, A Comparative Descriptive Model for Integral Translations. Dordrecht : Fortis Publications.

Venuti, L. (Ed.) (2000). The Translation Studies Reader. London and New York: Routledge.

Vinay, J.P. \& Darbelnet, J.(1995) comparative stylistics of French and English : a Methodology for Translation, Translated by J.C. Sager and M.J.Hamel. Amesterdam / Philadelphia : John Benjamins .

\section{References (Persian)}

$$
\begin{aligned}
& \text { قائم مقامي ، ح .1382. "سيندر لا": هيرمند } \\
& \text { قائم مقامي ، ح ـ01381. "داستان اسباب بازي" : هيرمند } \\
& \text { خدادادي (هيرمندي )، ر. } 1381 \text {."آنجا كه يِادهرو پٍايان ميابد": هواي تازه } \\
& \text { قانع شعرباف ، م ـ 1383.."علاالدين": دانش موسوي } \\
& \text { قانع شعر باف ، م .1383."ديو و فرشته ":خانه ادبيات } \\
& \text { قانع شعر باف ، م .1383. ."كوفي و دوستان" : دانش موسوي } \\
& \text { قانع شعر باف ، م .1383 ."در جستجوي نمو ": دانش موسوي } \\
& \text { قائم مقامي ، ح ـ } 1383 \text { ـ "شرك } 1 \text { و2": خانه ادبيات } \\
& \text { رستمي ، كـ .1383 ."مرد خفاشي": دانش موسوي }
\end{aligned}
$$

